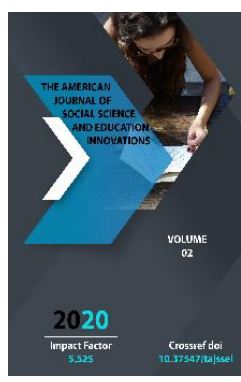

Copyright: Original content from this work may be used under the terms of the creative commons attributes 4.0 licence.

\section{Formation Of Modern, Intellectually Competent Youth Is A Priority Task}

\section{Z.Zulfikarova}

Teachers Of The Department Foreign Languages, Karshi Engineering And Economic Institute, Uzbekistan

\section{D.Jabbarova}

Teachers Of The Department Foreign Languages, Karshi Engineering And Economic Institute, Uzbekistan

\title{
ABSTRACT
}

This article analyzes the large-scale reforms in the field of education in our country, the adopted legal and regulatory documents, as well as information on the formation of young people as spiritually mature, mature individuals. It also generalizes the youth to issues such as the preservation and study of the rich spiritual heritage left by our great scholars and ancestors.

\section{KEYWORDS}

Education, spirituality, information technology, scholar, spiritual heritage, reform, law, manuscript, library, thinker.

\section{INTRODUCTION}

From the first years of independence, the country has undergone a process of radical reform of the education system, education from the point of view of the ideology of independence, the introduction of modern science. The essence of the implemented reforms has been gradually improved, and this process has continued with some shortcomings and successes.

At present, the quality, content and purpose of education in Uzbekistan are carried out in accordance with national traditions, using new modern experience. A number of radical changes in the industry, a number of decisions 
and decrees, the creation of legislation testify to the dynamic work in this area.

On September 23, 2020, the Law of the Republic of Uzbekistan No. 637 "On Education" was adopted. Article 4 of the law states "Basic principles in the field of education." In particular, the recognition of the priority of education, freedom of choice of education, non-discrimination in education, equal opportunities for education, inculcation of national and universal values in education, humane, democratic nature of education, continuity and consistency of education and other criteria.

Emphasis was placed on increasing the intellectual potential of young people, mastering the secrets of modern science and technology, as well as the inculcation of national and universal values in education and upbringing.

On September 30, 2020, the head of our state addressed an appeal to the representatives of the industry on the occasion of the Day of Teachers and Coaches. It reads: “... The unique and unique scientific and spiritual heritage of our great ancestors must become a vital program for us. This immortal heritage will always be with us and will always give us strength and inspiration. First of all, we need to irrigate the national education system in such a spirit. To do this, our scientists and specialists, our esteemed scholars must pass this spiritual treasure to today's generations in a simple and understandable, attractive form.

Today, it is important to search for, study and research the rich spiritual heritage left by our ancestors, and first of all, to provide quality education to our youth and bring them up in the spirit of respect and reverence for our rich spiritual heritage. Conditions are being created to enjoy the rare sources, works and spiritual heritage of our scholars, which are stored in libraries and manuscript collections around the world. To do this, first of all, we need to learn our native language, modern computer technology, effective use of the Internet, learning foreign languages, informing the world about our rich spiritual heritage, national traditions and values, the unique tourist potential of our country.

\section{MATERIALS AND METHODS}

Innovative technology to bring students to the attention of the world community, such as Bukhara, Khiva, Samarkand, Shakhrisabz, using a variety of modern interactive methods, such as "Collaborative reading", "Project work", "Innovative project". The use of achievements gives effective results.

Training a specialist who fully meets modern requirements is a requirement of the time. At present, a lot of positive work is being done in the country to educate the younger generation, to teach them to approach modern information technologies and to work with new techniques and technologies. The most important of them is "Distance Learning Techniques and Technology". The fact that many higher education institutions are organizing "master classes", in turn, gives positive results.

The uniqueness of our country, its unique nature, architectural monuments, sacred sites, the spiritual heritage created by great thinkers can be effectively introduced not only in our country, but also through the use of modern information technologies, its rich spiritual, material and intangible heritage.

To do this, first of all, our young people and students need to have a thorough knowledge, 
a thorough knowledge of their history, the rich spiritual heritage left by our ancestors, as well as a thorough knowledge of foreign languages.

\section{RESULT AND DISCUSSION}

If we look at the history, the famous Mamun Academy, which was established in Khorezm in the second half of the $X$ century and the beginning of the XI century, was one of the scientific institutions that had a positive impact on the development of science. In particular, the leaders of science, such as Muhammad alKhwarizmi, Abu Rayhan Beruni, Abu Ali ibn Sina, Abu Nasr Mansur ibn Iraq, first grew up in this scientific institution and reached the stage of perfection.

Also, in the IX-XII centuries, science in Movarounnahr rose and laid a real foundation for many branches and directions of modern science. In particular, the cornerstones of secular sciences such as mathematics, algebra, astronomy, medicine, geology, geodesy, geography, philosophy were laid during this period.

Muhammad Musa al-Khwarizmi (783-850), Ahmad al-Marwazi (780-880), Ahmad alFarghani (797-865), Abu Nasr al-Farabi (873950), Abu Bakr, who contributed to world science and civilization. Muhammad Narshahi (899-959), Abu Abdullah Khorezmi (died 997), Abu Rayhan Beruni (973-1048), Abu Bakr alKhwarizmi (935-993), Abu Ali ibn Sino (9801037), Ismail Jurjani (1042 -1136), Mahmud azZamahshari (1075-1149), Burhaniddin Marginoni (1123-1197), Mahmud Chagmini (early XII-XIII centuries). These great people have not only fundamental knowledge in a certain field, but also the idea that human perfection, spirituality, striving for perfection is one of the most noble qualities, which is very important today in the formation of a spiritually mature person, raising spirituality.

According to researchers, the East, especially the Central Asian region, was the source of two powerful scientific, cultural and spiritual upheavals in the IX-XII and XIV-XV centuries, which positively influenced the Renaissance in other parts of the world. rightly recognized by the world scientific community.

The importance of the rich spiritual heritage left by the scholars of the Middle East became the basis not only for our country, but also for the development of world science. The significance of the legacy of our great thinkers and scholars is not only in the field of science, but also in the field of spirituality and education. Preserving this priceless treasure and spreading it around the world is the duty of today's young generation. In order to carry out the above-mentioned tasks, young people must first have a thorough knowledge and thinking, be proud of the history of their homeland, their great ancestors, great commanders, nature, originality.

\section{CONCLUSION}

So, based on the above, special attention is paid to the formation of young people who are able to think independently, freely, harmoniously, mature spiritual and moral qualities in the current conditions of building a free democratic, legal, civil society in Uzbekistan. The study of the scientific heritage of Eastern thinkers in today's era of globalization is of great importance in the education and development of harmoniously, spiritually mature, intellectually gifted, educated youth, protecting them from alien influences. A deep understanding of the invaluable contribution of our great thinkers to 
world science, science and development is a very important issue.

\section{REFERENCES}

1. The Constitution of the Republic of Uzbekistan. -T., 2018.

2. Mirziyoev Sh. M. We will resolutely continue our path of national development and raise it to a new level. - Tashkent: Uzbekistan, 2017. - 592 p.

3. Address of the President of the Republic of Uzbekistan Sh.M.Mirziyoev to teachers and coaches on the occasion of October 1 "Teachers and Coaches Day". T., September 30, 2020.

4. Karimov I.A. Each of us is responsible for the development of the country. - Tashkent $\therefore$ Uzbekistan, 2001. T.9. -439 b.

5. Resolution of the President of the Republic of Uzbekistan Sh.M.Mirziyoev dated April 20, 2017 "On measures to further develop the system of higher education" PP-2909.

6. Law of the Republic of Uzbekistan "On Education". № -637, September 23, 2020.

7. Ochilov M. "New pedagogical technologies" / manual. - against: Nasaf, 2000.

8. Yusupov E. Spiritual maturity of youth. Tashkent: FAN, 1995.

9. www.uza.uz

10. www.lex.uz 